\title{
RESPONSE YIELD AND SOME GROWTH PARAMETERS OF BREAD WHEAT TO NANO AND NITROGEN FERTILIZERS
}

\author{
Mohammed Ali Hussain ${ }^{*}$, OMer AnWar OMer $^{* *}$ and Hogir Salim Mohammed ${ }^{* *}$ \\ *Dept. of Field Crops, College of Agricultural Engineering Sciences, University of Duhok, \\ Kurdistan Region, Iraq. \\ ** Dept. of Soil and Water sciences, College of Agricultural Engineering Sciences, \\ University of Duhok, Kurdistan Region, Iraq.
}

(Received: January 6, 2021; Accepted for Publication: February 9, 2021)

\begin{abstract}
The experiment was conducted to evaluate the influence of Nano and nitrogen fertilizers on grain yield and some growth parameters of bread wheat. The field experiment was carried out at the farm of field crop department, College of Agricultural Engineering Sciences, University of Duhok. The experimental units included of Nano fertilizer and four levels of nitrogen fertilizer (0, 20, 30 and $\left.40 \mathrm{Kg} \mathrm{ha}^{-1}\right)$. Each experimental units consisted of four rows for each varieties. The data analyzed according to factorial experiment in randomize block design with three replications. Results indicated that the significant response is obvious due to varieties, Holler variety was superior in leaf area $\left(60.98 \mathrm{~cm}^{2}\right)$, number of grain spike $^{-1}(49.46)$ and spike length $(11.05 \mathrm{~cm})$, while the nitrogen application exhibited a significant effect at nitrogen levels on all studied characters and the highest values for leaf area $\left(64.65 \mathrm{~cm}^{2}\right)$, total grain yield $\left(5.0635\right.$ ton/ha) and 1000 grain yield $(32.75 \mathrm{gm})$ was recorded at rate $40 \mathrm{Kg} \mathrm{ha}^{-1}$. For the interaction between Nano, nitrogen fertilizers and wheat varieties, the results indicated that the maximum values were recorded by Holler variety and $40 \mathrm{Kg} \mathrm{ha}^{-1}$ of nitrogen fertilizer, indicating that positive influence of nitrogen and Nano-fertilizer on yield, some growth parameters and grain yield were related to better performance of variety. For variation in agronomic efficiency (AE), the maximum value was recorded by Holler variety and also the results exhibited the highest value for grain yield response index (GYRI). The Holler cultivar was more than Adana-99 and the values ranged 15\% to 36\% compare with $7 \%$ to $16 \%$ for Adana-99.
\end{abstract}

KEY WORD: Nano fertilizer, Nitrogen, Bread wheat, Yield components.

\section{INTRODUCTION}

B read wheat (Triticum estivum L.) is one of the most important cereal crops of the world and is a staple food for about one third of the world's population (Hussain et al., 2002). The low of mean production in Iraq and Kurdistan Region due to using varieties of wheat with low yielding and in adequate nitrogen and rainfall.

Nitrogen is the important nutrient for growth and production of common wheat that effects on the plant growth and increases grain yield. Many researchers reported that the nitrogen application increased total grain yield of wheat (Fresew et al., 2018; Hussain et al., 2017; Beyenesh et al., 2017 and Amanel et al., 2002), however the increase of common wheat yield depend on the inadequate management of nitrogen fertilization and other factors such as varieties and rainfall.

Nitrogen is constituent of protein, enzymes, co-enzymes, nucleic acid, phytochromes and chlorophyll; it plays an important role in the biochemical processes to the plant, therefore, it's one of the most required nutrients by wheat crops (Wendling et al., 2007; Kutman et al., 2011). Nitrogen deficiency by the plant with a great impact on grain yield and it components. (Heinemann et al., 2006).

Wheat crop grow under a wide range of environmental conditions in Iraq. Plant breeder aim to develop wheat cultivars that consistently have high yield in a variety of environments. Wheat cultivars exposed to different soil types, soil fertility, moisture levels, temperatures and cultural practices. The adaptability of a variety is usually tested by the degree of its interaction 
with different environments. A variety or genotype considered to be more adaptive or stable if it has a high mean yield with low degree of fluctuation in yielding ability grown over diverse climatic conditions. Nitrogen consider as a key factor of yield and quality in the cereals. Numerous studies indicate that the nitrogen fertilization can increase both grain yield and grain protein content. Morsy et la., 2018, demonstrated that the interaction of nano fertilizer and nitrogen levels had a significant effect on FUE in the two growing season.

Morsy et al., 2018, indicated that the Nano fertilizer concentration and nitrogen levels had significant effects on most yield component. Nano technology is the most novel field of the twenty-one century and nano technology such as using nano scale particles is expected to play a vital role in developing improved systems for increasing the ability of crops to absorb nutrients (Rameshaiah and Japllavi, 2015). Nano fertilizer enhance growth parameters, plant height, leaf area, number of leaves per plant, dry matter production, chlorophyll production, rate of photosynthesis which result more production and translocation of photosynthesis to different parts of plant compare with traditional fertilizers (Ali and Al-Juthery, 2017 and Singh et al., 2017), therefore, the aim was to determine the extent effect foliar feeding of Nano-fertilizer and nitrogen fertilizer in yield and some parameters of wheat varieties growth and yield.

\section{MATERIALS AND METHODS}

The experiment consist of two wheat cultivar (Holler and Adina-99) was carried out at the farm of College of Agricultural Engineering Sciences/ Duhok University in silty clay soil
(Table 1), at latitude $36^{\circ}: 51^{-}: 40.9^{-} \mathrm{N}$, longitude $42^{\circ}: 51^{-}: 54.6^{=} \mathrm{E}$, and at elevation approximately 510 meter above the sea level, this study included the growth and yield of wheat by foliar application (Nano-fertilizer) containers, (N 6\%, P 3\%, K 17\%, Fe 4\%, Zn 4\%, Mn 2\%, Cu 0.5\%, B $0.5 \%$, Mo $0.1 \%$, Ca $1 \%, \mathrm{Mg} 3 \%$ and $\mathrm{S} 6 \%$ ), at rate $2 \mathrm{gm} \mathrm{L}^{-1}$ to all experimental units without control before the flowering stage, and nitrogen fertilizers with different levels (0, 20, 30 and 40 $\mathrm{Kg} \mathrm{ha}{ }^{-1}$ ). Each experimental unit consisted of four rows with $3 \mathrm{~m}$ length at a distance of $30 \mathrm{~cm}$ between lines with $5 \mathrm{~cm}$ in depth, the distance between each experimental units is $40 \mathrm{~cm}$ and seeds were sown at $(11 / 12 / 2019)$ with rate seed

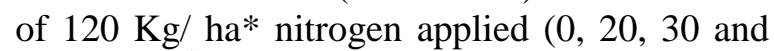
$\left.40 \mathrm{Kg} \mathrm{ha}^{-1}\right)$ using urea $(46 \%)$ at the tillering stages. While, the foliar application process was conducted at the start of flag leaf stage. All management practices for soil such as (land, soil preparation and tillage) and for plant like (pesticides or herbicides) were done as required. The data were recorded on plant height, flag leaf area, spike length, number of seed Spike ${ }^{-1}$, 1000seeds weight, seed spike weight and grain yield ton/ha. The rainfall and air temperature climatic data of the experiment field location, during growing season 2019-2020, were obtained from the meteorological Sumel station presented in (Table 2). Analysis of variance were analyzed using factorial experiment with randomize block design with three replication and Duncan Multiple Range Test (DMRT) using to compare between means of the treatment at 0.01 and 0.05 probability by using SAS 9.1 version software.

Agronomic Efficiency (AE)

Agronomic Efficiency (AE) as a nitrogen physiological parameters was calculated to Delogu et al., 1998 using the following equation:

$$
A E=\frac{\text { Grain yield at } \mathrm{N} \text { treatment }- \text { Grain yield at control (zero N) }}{\text { Applied } \mathrm{N} \text { at treatment }}(\mathrm{Kg} \text { grain } / \mathrm{Kg} \mathrm{N})
$$

\section{Grain Yield Response Index (GYRI)}

Grain Yield Response Index (GYRI) was calculated for each cultivars according to Fageria and Barbosa Filo (1981) using the following equation:

\author{
GYRI \\ $=$ Grain yield under high $\mathbf{N}$ level \\ Grain yield under control $N$ level \\ high $\mathrm{N}$ level - control $\mathrm{N}$ level
}


Table (1): Some physical and chemical properties of the studied soil before planting.

\begin{tabular}{|c|c|c|}
\hline Soil property & Unit & Depth $(0-30) \mathrm{cm}$ \\
\hline $\mathrm{pH}$ & (1:1) extract & 7.95 \\
\hline $\mathrm{EC}$ & $\mathrm{dS} \mathrm{m}^{-1}$ & 0.48 \\
\hline Available N & $\mathrm{mg} \mathrm{Kg}^{-1}$ & 109.35 \\
\hline Available P & $\mathrm{mg} \mathrm{Kg}^{-1}$ & 4.93 \\
\hline $\mathrm{K}^{+}$ & soluble cations (mmolc $\mathrm{L}^{-1}$ ) & 0.19 \\
\hline $\mathrm{Ca}^{+2}$ & & 1.62 \\
\hline $\mathrm{Mg}^{+2}$ & & 1.06 \\
\hline $\mathrm{Na}^{+}$ & & 0.64 \\
\hline $\mathrm{CO}_{3}^{-2}$ & soluble anions (mmolc $\left.\mathrm{L}^{-1}\right)$ & trace \\
\hline $\mathrm{HCO}_{3}^{-}$ & & 2.28 \\
\hline $\mathrm{Cl}-$ & & 0.52 \\
\hline $\mathrm{CaCO}_{3}$ & $\mathrm{~g} \mathrm{Kg}^{-1}$ & 215.3 \\
\hline O.M & $\mathrm{g} \mathrm{Kg}^{-1}$ & 16.5 \\
\hline CEC & Cmolc. $\mathrm{kg}^{-1}$ & 31.42 \\
\hline Sand & $\mathrm{g} \mathrm{Kg}^{-1}$ & 73.857 \\
\hline Silt & $\mathrm{g} \mathrm{Kg}^{-1}$ & 427.781 \\
\hline Clay & $\mathrm{g} \mathrm{Kg}^{-1}$ & 498.363 \\
\hline Soil texture & & Silty clay \\
\hline Bulk density & $\mathrm{g} \mathrm{cm}^{-3}$ & 1.37 \\
\hline
\end{tabular}

\section{Table (2): Average of the rainfall and air temperature climatic data of the experiment field location.}

\begin{tabular}{ccccc}
\hline years & months & rainfall mm & \multicolumn{2}{c}{${\text { temperature } \mathrm{C}^{\circ}}^{2}$} \\
\cline { 3 - 5 } & & 3 & 30.8 & Min. \\
\hline 2019 & Oct. & 30 & 22.1 & 18.2 \\
\hline 2019 & Nov. & 107 & 14.6 & 9.3 \\
\hline 2019 & Dec. & 89.5 & 10.6 & 6.9 \\
\hline 2020 & Jan. & 76 & 11.7 & 4.1 \\
\hline 2020 & Feb. & 310 & 18.6 & 4.3 \\
\hline 2020 & Mar. & 55 & 19.8 & 9.8 \\
\hline 2020 & Apr. & 16.5 & 21.2 & 10.7 \\
\hline 2020 & May & & & 11.6 \\
\hline
\end{tabular}

\section{RESULTS AND DISCUSSION}

ANOVA Table revealed that the cultivar (Holler) had highly significant effect on leaf area, plant high and spike length, significant effect for seed number spike ${ }^{-1}$ and nonsignificant effect on grain yield and 1000 grain weight, while the nitrogen level had highly significant effect for all characters. The interaction of cultivars and nitrogen fertilization level had highly significant effect on leaf area and significant for seed number spike ${ }^{-1}$ and spike length, whilst, the other characters were not significant effect Table 3. These results confirm the findings of (Fersew et al., 2018; Dere, 2017 and Tomado et al., 2015). 
Table (3): Analysis of variance for yield and its components under different levels of nitrogen fertilizer.

\begin{tabular}{|c|c|c|c|c|c|c|c|c|}
\hline \multirow[t]{2}{*}{ Source } & \multicolumn{8}{|c|}{ Mean S } \\
\hline & $\overline{D F}$ & $\begin{array}{l}\text { Leaf area } \\
\text { cm2 }\end{array}$ & $\begin{array}{l}\text { Plant height } \\
\text { (cm) }\end{array}$ & $\begin{array}{l}\text { Total weight in } \\
\text { ton } \mathrm{ha}^{-1}\end{array}$ & $\begin{array}{l}\text { Weight of } \\
1000 \text { seeds } \\
\text { (gm) }\end{array}$ & $\begin{array}{c}\text { Seed } \\
\text { number/ } \\
\text { spike }\end{array}$ & $\begin{array}{l}\text { Seed weight/ } \\
\text { spike (gm) }\end{array}$ & $\begin{array}{c}\text { spike length } \\
\mathrm{cm}\end{array}$ \\
\hline Block & 2 & 0.498 & 0.042 & 0.0438 & $5.071^{*}$ & 2.85 & 0.0099 & $0.185^{\star}$ \\
\hline Varieties (A) & 1 & $66.634^{\star \star}$ & $486.00^{\star \star}$ & 0.0159 & 1.98 & $29.04^{*}$ & 0.0029 & $0.454^{\star \star}$ \\
\hline Fertilizer (B) & 3 & $122.65^{\star \star}$ & $1016.11^{\star *}$ & $3.9240^{* *}$ & $20.84^{\star \star}$ & $297.97^{\star *}$ & $0.3090^{\star \star}$ & $13.343^{\star \star}$ \\
\hline$A^{\star} B$ & 3 & $24.99^{\star *}$ & $21.45^{\star \star}$ & 0.2466 & 0.82 & $25.75^{\star}$ & 0.0097 & $0.182^{*}$ \\
\hline Error & 14 & 0.47 & 9.33 & 0.0997 & 1.096 & 4.77 & 0.012 & 0.044 \\
\hline
\end{tabular}

*, ** significant at 0.05 and 0.01 respectively

\section{Varietal differences}

Mean values for seven characters are shown in Table 4. The mean performance of the two varieties. The variety Holler was superior in leaf are $\left(60.98 \mathrm{~cm}^{2}\right)$, number of grain spike ${ }^{-1}(49.46)$ and spike length (11.05). While, the Adana-99 variety was performance in plant height $(82.17$ $\mathrm{cm})$. The results in the same table exhibited that no significant between the varieties in grain yield, 1000 grain weight and grain weight spike

1 . The results indicating that the differences between Holler and Adana-99 was due to, the varieties variability in most characters may be affected not only physiological traits but also by the nitrogen supply in soil and also, this implies varieties differ in absorption and utilization of nitrogen depend on the structure of genotypes. Varietal differences in yield components among wheat cultivars were obtained by (Aleum et al., 2019; Debre, 2017 and El-Metwally and Suady, 2009).

Table (4): Mean of varieties of bread wheat on yield and yield components under different nitrogen levels.

\begin{tabular}{cccccccc}
\hline Varieties & \multicolumn{6}{c}{ Means } \\
\cline { 2 - 7 } & $\begin{array}{c}\text { Leaf area } \\
\mathbf{c m}^{2}\end{array}$ & $\begin{array}{c}\text { Plant height } \\
\mathbf{c m}\end{array}$ & $\begin{array}{c}\text { Total weight in } \\
\text { ton ha }\end{array}$ & $\begin{array}{c}\text { Weight of } 1000 \\
\text { seeds (gm) }\end{array}$ & $\begin{array}{c}\text { Seed } \\
\text { number/ } \\
\text { spike }\end{array}$ & $\begin{array}{c}\text { Seed weight/ } \\
\text { spike (gm) }\end{array}$ & $\begin{array}{c}\text { spike length } \\
\text { cm }\end{array}$ \\
\hline Holler & $60.98 \mathrm{a}$ & $73.17 \mathrm{~b}$ & $4.4355 \mathrm{a}$ & $30.83 \mathrm{a}$ & $49.46 \mathrm{a}$ & $1.51 \mathrm{a}$ & $11.05 \mathrm{a}$ \\
\hline Adana-99 & $57.64 \mathrm{~b}$ & $82.17 \mathrm{a}$ & $4.3840 \mathrm{a}$ & $31.39 \mathrm{a}$ & $47.26 \mathrm{~b}$ & $1.49 \mathrm{a}$ & $10.78 \mathrm{~b}$ \\
\hline
\end{tabular}

Mean bearing different letter within each column different significantly at 0.05 level.

\section{Effect of Nitrogen Fertilization}

Data presented in Table 5, exhibited the effect of nitrogen levels on seven characters of bread wheat varieties. The results showed that a significant effect of all nitrogen levels on all studies characters comparison with control and also, the rate $40 \mathrm{Kg} \mathrm{ha}^{-1}$ clearly, the highest values for leaf area $\left(64.65 \mathrm{~cm}^{2}\right)$, plant height
$(88.33 \mathrm{~cm})$, total grain yield $(5.0635 \mathrm{ton} / \mathrm{ha})$, 1000 grain weight $(32.75 \mathrm{~g})$, number of grain spikr-1 (65.97), weight of grain spike ${ }^{-1}(1.71 \mathrm{~g})$ and spike length (12.52) respectively, followed by the rate $30 \mathrm{Kg} \mathrm{ha}^{-1}$ and recorded high mean values comparison with the rate of $20 \mathrm{Kg} \mathrm{ha}^{-1}$. From the results in Table 5 indicated that the increase in yield and some studied characters, 
the variation with increase nitrogen, the rate up to adequate level might be due to the role of nitrogen in increasing the leaf area and promote photosynthesis efficiency which promote dry matter production and increase yield and yield components. These results are in accordance with report of (Lopez-Bellido et al., 2005; Saudy et al., 2008; Nemat et al., 2013 and Fresew et al.,

2018).

Table (5): Effect of nitrogen levels on yield and yield components on bread wheat cultivars.

\begin{tabular}{|c|c|c|c|c|c|c|c|}
\hline \multirow[t]{2}{*}{ Treatments } & \multicolumn{7}{|c|}{ Means } \\
\hline & $\begin{array}{c}\text { Leaf area } \\
\mathrm{cm}^{2}\end{array}$ & $\begin{array}{c}\text { Plant height } \\
\text { cm }\end{array}$ & $\begin{array}{l}\text { Total weight in } \\
\text { ton } \mathrm{ha}^{-1}\end{array}$ & $\begin{array}{c}1000 \text { seeds } \\
\text { Weight }(\mathrm{gm})\end{array}$ & $\begin{array}{c}\text { Seed } \\
\text { number/ } \\
\text { spike }\end{array}$ & $\begin{array}{c}\text { Seed weight/ } \\
\text { spike (gm) }\end{array}$ & $\begin{array}{c}\text { spike length } \\
\mathrm{cm}\end{array}$ \\
\hline Control & $54.39 \mathrm{~d}$ & $59.50 \mathrm{c}$ & $3.2453 \mathrm{c}$ & $28.51 \mathrm{c}$ & $40.32 \mathrm{~d}$ & $1.18 \mathrm{c}$ & $9.18 d$ \\
\hline N 20 kg & $57.03 \mathrm{c}$ & $77.17 \mathrm{~b}$ & $4.5097 \mathrm{~b}$ & $31.06 \mathrm{~b}$ & $45.83 \mathrm{c}$ & $1.52 \mathrm{~b}$ & $10.23 \mathrm{c}$ \\
\hline N 30 kg & $61.18 \mathrm{~b}$ & $85.67 \mathrm{a}$ & $4.8205 a b$ & $32.10 \mathrm{ab}$ & $50.32 \mathrm{~b}$ & $1.60 \mathrm{ab}$ & $11.72 \mathrm{~b}$ \\
\hline $\mathrm{N} 40 \mathrm{~kg}$ & $64.65 \mathrm{a}$ & $88.33 \mathrm{a}$ & $5.0635 \mathrm{a}$ & $32.75 \mathrm{a}$ & $56.97 \mathrm{a}$ & $1.71 \mathrm{a}$ & $12.52 \mathrm{a}$ \\
\hline
\end{tabular}

Mean bearing different letter within each column different significantly at 0.05 level.

\section{Effect of Interaction}

Generally, increasing nitrogen up to $40 \mathrm{Kg}$ ha $^{-1}$ with each tested cultivars showed in Table 6, maximum values for leaf area, plant height, grain yield, 1000 grain weight, number of grain spike $^{-1}$, weight of grain spike ${ }^{-1}$, and spike length. From the same table the Holler variety was superior in leaf area $\left(61.17 \mathrm{~cm}^{2}\right)$, grain yield (5.192 ton/ha), number of grain spike ${ }^{-1}(57.43)$ and grain weight spikt $^{-1}(1.77 \mathrm{~g})$, at rate of 40 nitrogen level. While, the Adana-99 variety was performance in plant height $(91.33 \mathrm{~cm}), 1000$ grain weight (33.21g) and spike length
$(12.57 \mathrm{~cm})$ at rate of 40 nitrogen levels. From the result in the same table, the Holler variety was response to the different nitrogen levels in most characters compare with Adana-99 variety, indicating that the positive effect of nitrogen fertilization levels on grain yield and yield components were related to better performance of grain yield components and the response of variety may be effected not only physiological traits but also by nitrogen supply in soil, similar results were obtained by (Ali and Al-Juthey 2017; Beyensh et al., 2017 and Izzat et al., 2020).

Table (6): Effect of interaction between nitrogen levels and bread wheat cultivars on yield and yield components.

\begin{tabular}{|c|c|c|c|c|c|c|c|c|}
\hline \multicolumn{2}{|c|}{$\begin{array}{c}\text { Combination } \\
N^{*} V\end{array}$} & \multirow{2}{*}{$\begin{array}{c}\begin{array}{c}\text { leaf area } \\
\mathbf{c m}^{2}\end{array} \\
54.84 \mathrm{e}\end{array}$} & \multirow{2}{*}{$\begin{array}{c}\begin{array}{c}\text { plant high } \\
\text { cm }\end{array} \\
52.33 \mathrm{f}\end{array}$} & \multirow{2}{*}{$\begin{array}{c}\text { Total weight in } \\
\text { ton } \text { ha }^{-1} \\
2.9838 \mathrm{C}\end{array}$} & \multirow{2}{*}{$\begin{array}{c}\text { weight of } \\
1000 \text { seeds } \\
\text { gm }\end{array}$} & \multirow{2}{*}{$\begin{array}{c}\text { Seed number. } \\
\text { spike }^{-1}\end{array}$} & \multirow{2}{*}{$\begin{array}{c}\begin{array}{c}\text { seed weight } \\
\text { spike }^{-1} \text { gm }\end{array} \\
1.19 \mathrm{c}\end{array}$} & \multirow{2}{*}{$\begin{array}{c}\text { spike length } \mathbf{c m} \\
9.33 \mathrm{e}\end{array}$} \\
\hline Holler & No & & & & & & & \\
\hline & N20 & $57.01 \mathrm{~d}$ & $72.67 \mathrm{~d}$ & $4.7088 \mathrm{~b}$ & $31.05 b$ & $48.40 \mathrm{c}$ & $1.54 b$ & $10.60 \mathrm{c}$ \\
\hline & N30 & $62.89 \mathrm{~b}$ & $82.33 \mathrm{c}$ & $4.8575 a b$ & $31.39 a b$ & $53.23 \mathrm{~b}$ & $1.55 \mathrm{~b}$ & $11.80 \mathrm{~b}$ \\
\hline & N40 & $69.17 \mathrm{a}$ & $85.33 \mathrm{bc}$ & $5.192 \mathrm{a}$ & $32.29 \mathrm{ab}$ & $57.43 \mathrm{a}$ & $1.77 \mathrm{a}$ & $12.47 \mathrm{a}$ \\
\hline Adana-99 & No & $53.94 \mathrm{e}$ & $66.67 \mathrm{e}$ & $3.5069 \mathrm{c}$ & $28.45 \mathrm{c}$ & $41.87 \mathrm{de}$ & $1.18 \mathrm{c}$ & $9.03 \mathrm{e}$ \\
\hline
\end{tabular}




\begin{tabular}{|c|c|c|c|c|c|c|c|}
\hline $\mathrm{N} 20$ & $57.04 d$ & $81.67 \mathrm{c}$ & $4.3106 \mathrm{~b}$ & $31.08 \mathrm{~b}$ & $43.27 \mathrm{~d}$ & $1.50 \mathrm{~b}$ & $9.87 \mathrm{~d}$ \\
\hline N30 & $59.47 \mathrm{c}$ & $89.00 a b$ & $4.7836 a b$ & $32.816 \mathrm{a}$ & $47.40 \mathrm{c}$ & $1.64 \mathrm{ab}$ & $11.63 \mathrm{~b}$ \\
\hline N40 & $60.18 \mathrm{c}$ & $91.33 a$ & $4.935 \mathrm{a}$ & $33.216 \mathrm{a}$ & $56.50 \mathrm{ab}$ & $1.66 \mathrm{ab}$ & $12.57 \mathrm{a}$ \\
\hline
\end{tabular}

Mean bearing different letter within each column different significantly at 0.05 level.

\section{Agronomic Efficiency}

'Variation in agronomic efficiency (AE) appeared to result differences in two varieties using in this study Table 7. The maximum AE was exhibited with Holler, to mention that increase of nitrogen enhanced grain yield by $16 \%$ and $9 \%$ at second level $40 \mathrm{Kg}$ nitrogen, while the Adana-99 appeared low AE for different levels of nitrogen and the value ranged $16 \%$ to $18 \%$ with adding and $30 \mathrm{Kg} \mathrm{ha}^{-1}$. From the results at the same table, it showed be that genotypic variation in nitrogen efficiency could generally be attributed to high nitrogen uptake or in high nitrogen utilization by different varieties. It should be concluded that nitrogen level in the soil could be manipulated together with genetic diversity of the crop as a breeding tool for wheat cultivars development through improving nitrogen uptake or nitrogen utilization efficiency. These result are in good agreement with finding by (Saudy et al., 2008).

\section{Grain Yield Response Index}

Grain Yield Response Index (GYRI) was calculate at zero and $40 \mathrm{Kg} \mathrm{N}^{-1}$ as low and high nitrogen levels respectively. Grain yield response index is an indication to the efficient of wheat cultivars for producing higher grain yield at low nitrogen and their response to increase nitrogen fertilizer rates accordingly, it is possible to classify wheat cultivars into four groups: (1) Efficient and Responsive (ER) that produce high grain yield at low as well as high rates of nitrogen fertilizer. (2) Efficient and not Responsive (ENR) that produce high grain yield at low nitrogen rate with lower response to increase nitrogen fertilizer than (ER). (3) Not Efficient but responsive (NER) that has low grain yield with response to increase nitrogen fertilizer; and. (4) Neither Efficient not Responsive (NENR) that has low grain yield with low response to increase nitrogen fertilizer. From the data in the Table 6, the GYRI for Holler cultivar was more than Adana-99 cultivar and the values ranged $15 \%$ to $36 \%$ compare with $7 \%$ to $16 \%$ for Adana-99 cultivar. Differences between two cultivars for GYRI were largely due to variation in utilization of accumulated nitrogen, but with high nitrogen rate they were largely due to variation in up take efficiency. The variety Holler was performance in (ER) and (GYRI) at different rate of nitrogen, this in fluctuation in grain yield due to genetic structure of cultivars in leaf area, plant height, number of leaves plant ${ }^{-1}$ and yield components. This support with finding the nano fertilizer and nitrogen levels effect on yield of bread wheat (Saudy et al., 2008; Nemat et al., 2013 and Aleum et al., 2019).

Table (7): Agronomic efficiency and grain yield response index for Holler and Adana-99 varieties. Nitrogen levels $\quad$ Varieties

\begin{tabular}{ccccc} 
& \multicolumn{2}{c}{ Holler } & & Adana-99 \\
\cline { 2 - 5 } & AE & GYRI & AE & GYRI \\
\hline 20 & $11 \%$ & $5 \%$ & $16 \%$ & $7 \%$ \\
\hline 30 & $27 \%$ & $20 \%$ & $18 \%$ & $14 \%$ \\
\hline 40 & $36 \%$ & $36 \%$ & $16 \%$ & $16 \%$ \\
\hline Average & $25 \%$ & $20 \%$ & $17 \%$ & $12 \%$ \\
\hline
\end{tabular}




\section{CONCLUSION}

The results of this study showed that the Nano and nitrogen fertilizers which were used for bread wheat production and have not reflected and also in this experiment, application of $2 \mathrm{~g} / \mathrm{L}$ of Nano fertilizer and $40 \mathrm{Kg} \mathrm{ha}^{-1}$ of nitrogen fertilizer caused high a variability of nitrogen nutrient for plant growth parameters and improved wheat crop productivity.

\section{REFERENCES}

Aleum D., Firew M. and D. Tadesse. (2019). Genetic variability studies on bread wheat (Triticum estivum L.) genotyoes. J. of plant breeding and Crop Scince. 11(2): 41-54.

Ali N. S. and H. A. Al-Juthey. (2017).The application of nanotechnology for micronutrient in agriculture production (review article). The Iraqi J. of Agr. Sci. 9(48): 441-489.

Amanel, G. Kuhne. R. F., Tanner. D. G. and P.I.G. Vlet. (2002). Pecovery of $15 \mathrm{~N}$ labeled urea applied to wheat in the Ethiopian Higlands aflected by P fertilization. J. Agron. Crop Sci.: 189: 30-38.

Amare A. (2017). Response of bread wheat varieties to different seedling rate for growth, yield and yield components in Komboleha. Ethiopia. J.of Bio. Agric. And Healthcare (7) (23):7991.

Beyenesh. Z.' Nigussie D. and A. Fetien. (2017). Yield and nutrient use efficiency of bread wheat as influenced by time and rate of nitrogen application in Enderta, Tigray, Nothern Ethiopia. Open Agriculture 2, 1: 611624.

Debre M. (2017). Response of bread wheat (Triticum estivum L.) varieties to different seed rate for growth, yield and yield components in Kombolcha District, North. Eastern Ethiopia. J. of Biology, Agric. And Healthcare. 7(23): 79-91.

Delogu G., Cattivelli L., Pecchioni N., Falcis D. De., Muagiore T. and A. M. Stanca. (1998). Uptake and agronomic efficiency of nitrogen in winter barley and winter wheat. Eur. J. Agron. 9: 1120.

El-Metwally and Suady. (2009). Herbicide tankmixuers efficiency on weed and wheat productivity. Annals. Agric. Sci. Moshtohor. 47(2): 99-109.

Fageria N. K. and M. C. Barbosa Filho (1981). Screening rice cultivars for higher efficiency of phosphorus absorption. Pesq. Agropec. Bras. Brasilia. 26:777-782.

Fresew B., Nigussie D., Adamu M. and Tamado. (2018). Effect of nitrogen fertilizer rate on grain yield and nitrogen uptake and use efficiency of bread wheat (Triticum estivum L.) varieties on the vertisols of central high land of Ethiopia. Agric. And Food secur. 7(78): 2-12.

Heineman, A.B.,Stone, L. F., Didonet, A. D., Trindade, M. G. and A. D. Canovas. (2006). Eficienica de use da radiacao solar na prodatividade de trigo decorrent da adubacao nitrogenada. Revist Brasileira de Engenharia Agricolae Ambiental. 10, 2: 352-356.

Hussain, M.A., Dohuki, M.S.S. and Ameen, H.A., (2017). Response of some bread wheat (Triticum aestivum L.) cultivars to nitrogen levels. Kufa Journal for Agricultural Sciences, 9(4), pp.365-390.

Hussain. M, Ftohar, H. and S. Hatn. (2002). Growth, yield and quality response at three wheat $(\mathrm{T}$. estivan $\mathrm{L}$ ) varieties to different levels of $\mathrm{N}, \mathrm{P}$, K. Int. J. Agric. Bio. (4), (3) 362-364.

Izzat S. A. T.; Elfadi M. E. E.; Mohamed A. S. I.; AbuSefyan I. S. and O. S. Abdulla. (2020). Genetic grain in wheat grain yield and nitrogen use efficiency at different nitrogen levels in an irrigated hot environment. Hindawi. Com/jounals/ija/2020/9024671.

Kutrnan, U. B., Yidiz, B. and I. Cakmak, (2011). Effect of nitrogen on uptake, remobilization and partitioning of zinc and iron throughout the development of durum wheat. Plant and soil, 342, 1-2: 149-164.

Lopez-Bellido L., Lpez-Bellido R. J. and R. Redondo. (2005). Nitrogen efficiency in wheat under rain fed Mediterranean condition as affected by split nitrogen application. Field crop. Res. 94:86-97.

Morsy A.S.M., A. A. Awadalla and M. M. Sherif. (2018). Effect of Irrigation, Foliar spray with nano-fertilizer (Lithovit) and nitrogen levels on productivity and quality of Durum wheat under Toshka conditions. Assiut. J. Agric. Sci., 4993): 1-26.

Naderi M.; A. A. D. Shahraki and R. Naderi. (2011). Application of nanotechnology in the optimization of formulation of chemical fertilizers. Iran J. Nanotech. 12: 16-23.

Nemat A. N. O. Urldin, Saudy H. S., Ashmay F. and H. M. Saed. (2013). Grain yield response index of bread wheat cultivars influenced by nitrogen levels. Annal. Of Agricultural Science. 58(2): 147-152.

Rameshaiah G. N. and S. Jpallavi. (2015). Nanofertilizer a nano sensors an attempt for developing smart agriculture. Intern. J. Engineering Res, and General Sci. 3(1): 314320.

SAS Institute. (2002). SAS/ATAT User's Guide. In: Vresion 9.1., SAS Institute Cary, NC.

Saudy H. S., Habbal M. S. and Kh. Iman. (2008). Genotypes $\mathrm{x}$ environment interaction for grain 
yield wheat genotypes tested water stress conditions. Sci. Int. 992): 133-137.

Singh M. D.; Gautam C.; Patidar O. P.; Meena H. M.; Rasha G. and Vishwajith. (2017). Nano fertilizer is a new way to increase nutrients use efficiency in crop production. International $\mathrm{J}$. of Agri. Review article. International J. of Agri. Sci. 9(7): 3831-3833.

Tamado T., Dawit D., and J. Sharma. (2015). Effect of weed management methods and nitrogen fertilizer rates on grain yield and nitrogen use efficiency of bread wheat in Southern Eth. East Afr. J. Sci. 9(1): 15-30.

Wendling, A., Eitz, F.L.F., and T. Lovato. (2007). Recomendacao de adubacao nitrogenada para trigoem sucessaoao milhoe soja sob Sistema plantio direto no paraguai. Revista Brasilerra de Ciencia do Solo. 31 (5): 985-994.

رهنكُهدانا بهرهه و جهندين بيقهريّن گه شهيا شينكاتيا گهنمى نانى بوّ يهينى نانو و يهينى نايتروجينى

يوخته

ئهث قهكولينه ل زهفى ييّن تاقيكرنان ل كوليزا ئهندازيارييا جاندنى ل زانكويا دهوكى هاتينه

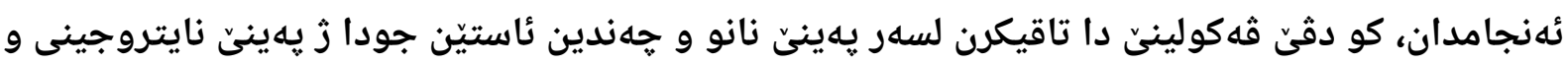

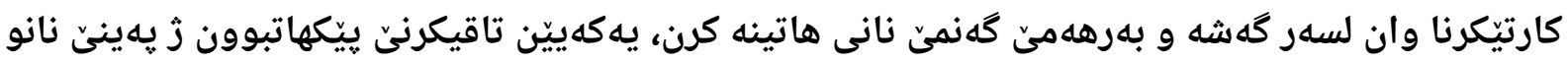

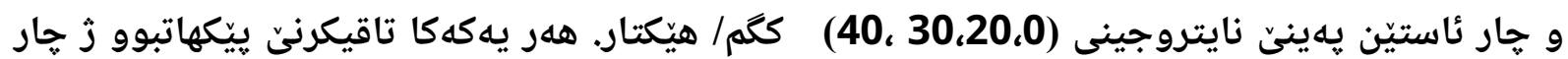
هيّان بوّ ههر جوينهكى بوّماوهيى (جينوتايب). شروڤهكرنا ئهنجامان لدويف تاقيكرنيّن جيهانى يا كهرتيّن ههرهمهكى ييّن تهقگَ ب سيّ دووبارهبوويان هاتنه بريّفهبرن. ئهنجام ب ئهفى رهنگى دياربوون؛ ههبوونا

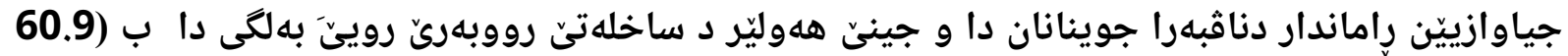

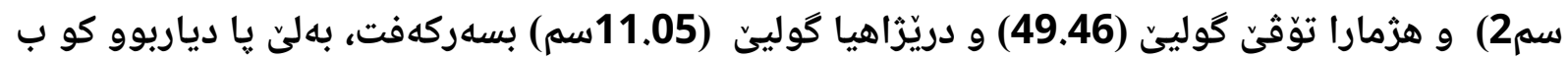
زيّدهرنا نايتروجينى جياوازى ييّن بلند ييّن راماندار دناقبهرا ئاستيّن جودا جودا يهيدابوينه. و و كارتيّكرنا

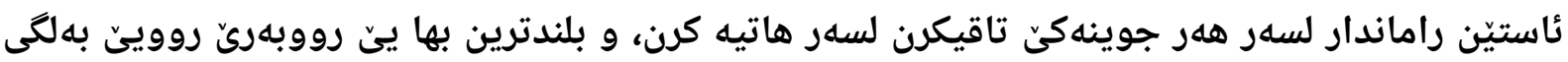
(64.65 سم2) و داهاتئ دندكان هـ ميان (5.0635 ته ن ل هيّكتار) و بارستهيا هزار دندكان (32.72غم) ل ئاستى 40 كگم/هيكتار هاتينه

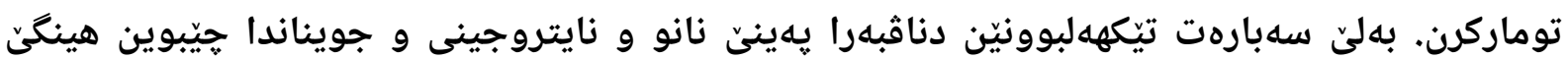

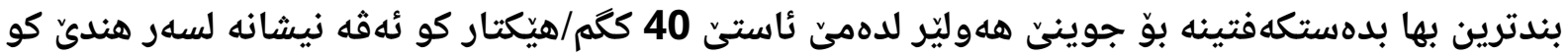

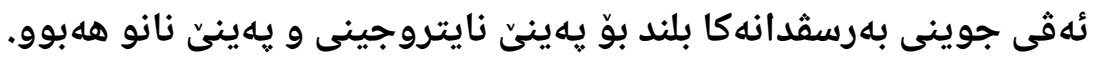

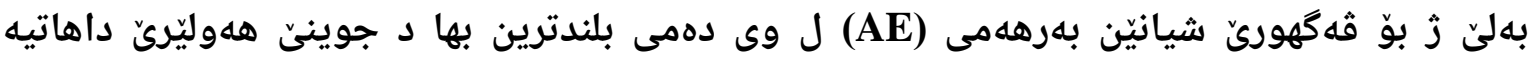
توماركرن، ههروهكى ههمان جوين بلندترين بها وهك نيشان لسهر بهرههمي دندكان (GYRI) توماركرى، كو

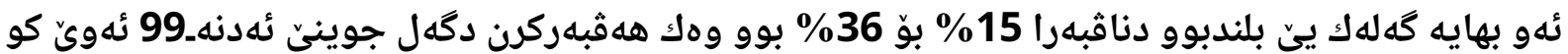

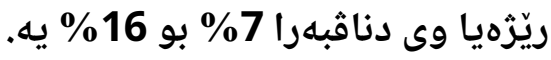

شوكه يهيف: يهينى نانوّ، يهينى نايتروّجينى، گهنمى ئارى، يِيكهاتيّن بهرهه مى. 
استجابة الحاصل وخواص النمو الخضري لحنطة الخبز لسماد النانو والسماد النايتروجيني

الخلاصة

أجريت التجربة لتقييم تأثيرسماد نانو ومستويات مختلفة من النيتروجين على حاصل نمو وبعض معاملات النمو حنطة الخبز. طبقت الدراسة في حقل تجارب قسم المحاصيل الحقلية, كلية الهندسة الزراعية جامعة

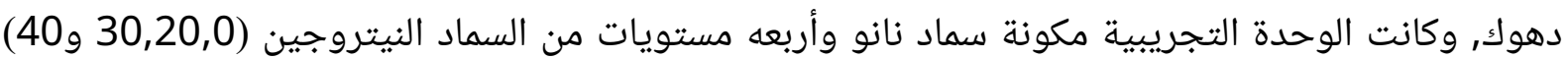
كغم في الهكتار. لكل وحدة تجريبية زرعت تركيب وراثي في أربعه خطوط. جرى تحليل النتائج وفق نظام

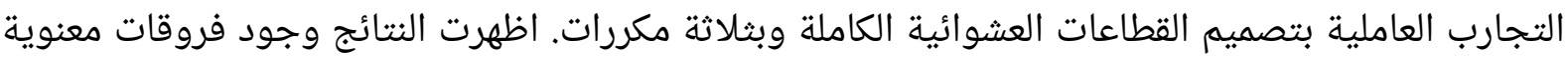
بين الاصناف وتفوق الصنف هولير في صفة المساحه الورقية (60.9 سم²) وعدد البذور سنبله (49.46) وطول السنبله (11.05 سم), واظهرت اضافة النيتروجين فروقات عالية المعنوية بين المستويات المختلفة. وكان تأثير

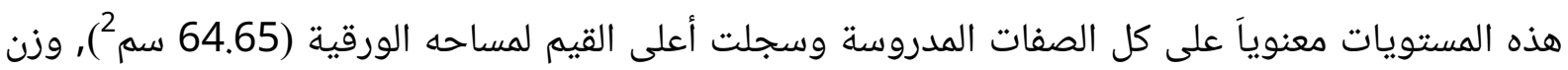
البذور (5.0635 طن في الهكتار) ووزن الف حبه (32.72غم) عند مستوى 40 كغم في الهكتار.

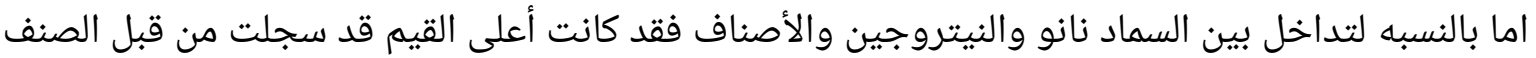
هولير وعند معدل 40 كغم في الهكتار مما يدل على ان هذا الصنف كانت أستجابته عالية للسماد النيتروجين وسماد نانو. اما بالنسبة الى معامل كفاءه المحصول (AE) فأن أعلى القيم سجلت من قبل الصنف هولير, كما سجل نفس الصنف قيم عالية لدليل الحاصل البذور( GYRI) تراوحت بين 15\% الى 36 \% \%

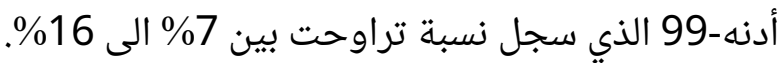

الكلمات المفتاحية: سماد نانو, سماد النيتروجين, حنطة خبز ومكونات الحاصل. 